\title{
Applying building information modelling in environmental impact assessment for urban deep excavation projects
}

\author{
$\underline{\text { Siang-Rou Lu }}^{1}$, I-Chen Wu ${ }^{1 *}$, and Bin-Chen Benson Hsiung ${ }^{1}$ \\ ${ }^{1}$ Department of Civil Engineering, National Kaohsiung University of Applied Sciences, \\ Kaohsiung, Taiwan \\ *Corresponding author (kwu@kuas.edu.tw)
}

\begin{abstract}
Purpose Due to the rapid development of cities, underground structures, such as deep excavations and tunnels have been widely used to increase underground space. Since these underground structures are often adopted in old and crowded town area, accidents may easily do serious damage to adjacent structure and even cause some casualties. Professional engineering knowledge and experience can reduce or avoid this chain of events. But it is undeniably the case that in more complex urban engineering environments, risks are higher. Construction project teams must therefore consider a wide variety of information when managing risks and making project decisions. Urban deep excavation construction might cause unfavourable effects on the ground and to nearby structures. Environmental impacts need to be evaluated and monitored during the deep excavation construction. Generally, construction project teams will set up monitoring instruments to control and monitor overall environmental status, especially when retaining wall construction, retaining wall excavation, and during groundwater pumping. Voluminous monitoring data and project information are usually created along the delivery processes of construction. It is difficult to view and manage them comprehensively. Method Our research employs the concept of building information modelling (BIM) in environmental impact assessment for urban deep excavation projects. BIM is a relatively new technology that facilitates better information integration and management. Many engineering companies employ BIM for information integration, visualization, and parametric design, to reduce both the duplication of work and the complexity of interface integration. In this research, a 3D-building model, an excavation model, environmental conditions, the results of ground surface settlement analysis, and measurement and monitoring data, were integrated into our system to assist construction project teams to execute environmental impact assessment accurately. The risks and issues affecting safety of excavation and nearby structures might be recognized earlier through conveying information visually in this system. Construction project teams can then handle them immediately. The implementation of the system was carried out in the MicroStation Visual Basic for Applications (MVBA) environment. The Bentley MicroStation supports visualization of the 3D-model and provides some capabilities for 3D-object manipulation and information query. Results \& Discussion This system can provide construction project teams a full view of the ongoing project, along with functions to integrate and display information multidimensionally. We will demonstrate the functionalities we developed and verify its feasibility in the O6-underground station of the Kaohsiung metro system.
\end{abstract}

Keywords: BIM, environmental impact assessment, deep excavation, monitoring

\section{INTRODUCTION}

Due to fast development of the city, underground structures, such as deep excavation and tunnel have been widely used for increasing of underground space. Since these underground structures are often adopted in old and crowed town area, accidents caused by them may easily make serious damage to adjacent structure and even some causality. Especially, ground settlement is thought to be the greatest impact for nearby environment. At present, the empirical methods and finite element method are two commonly used tools to predict the ground settlement induced by excavation. Through collection and evaluation of data of surface settlement from underground construction in various places, Peck ${ }^{1}$ first defined the possible influence zone next to the excavation. Bowles ${ }^{2}$ recommended a procedure to esti- mate excavation- induced ground surface but lateral wall deflection has to be first calculated. Clough and O'Rourke ${ }^{3}$ proposed various types of envelopes of excavation- induced ground surface settlement and they are mainly classified by ground conditions. Ou et al. ${ }^{4}$ developed a method to predict the ground surface settlement on the basis of studies and type of ground surface settlement and it was concluded that in principle there are two types of settlement curves, the spandrel and the concave and it appears the magnitude of wall deflection in cantilever model would define the type of settlement curve. Similarly, various studies have been conducted so far for application of numerical analyses in deep excavations but they are not addressed here due to the limit of paper length. Professional engineering knowledge and experience can interpret the above mentioned 
results to avoid and reduce the accidents occurring. But, it is not to be denied that design and construction of deep excavation becomes more difficult as excavation depth is deeper and surrounding environment becomes more complicated. Therefore, the construction project team must consider a wide variety of information to assess environment impact when managing risks and making project decisions. Treicher ${ }^{5}$, an experimental psychologist, has proved that of the information human beings received, $83 \%$ is by sight sense, this shows the information visualization is essential for communication and information distribution. With the growth of using visualization techniques in construction, Building Information Modeling and Geographic Information System have recently attained a widespread contribution in visualization of construction progress ${ }^{6}$. Especially, $\mathrm{BIM}$ is a relatively new technology that facilitates better information integration and management. Many engineering companies employ BIM for information integration, visualization and parametric design, to reduce both the duplication of work and the complexity of interface integration. For these reasons, this research applies BIM in integration the relevant data (ex. 3D building model, excavation model, stratum data, monitoring data, the results of ground settlement analysis and so on) in urban deep excavation projects for environmental impact assessment. Moreover, BIM system can convey the different kinds of information for assisting construction project team to manage risk and make project decisions.

\section{Methodology}

The number of deep excavation pits in city centers is increasing every year. Buildings, streets, surrounding excavation locations and design of very deep basements make excavations formidable projects. Deep excavation projects are widely understood as highrisk events, and so much attention to safety and stability is required. This research took advantage of BIM functionalities in environmental impact assessment for urban deep excavation projects. The concept is to integrate the required data and then to visualize them appropriately and effectively to assist construction project teams to effectively assess environment impacts as shown in Figure 1. Further discussion of the information requirements for each aspect will be presented in the following section.

\section{Building Information Modeling}

BIM becomes a shared knowledge resource to support environmental impact assessment. The sources of integration in BIM in this research are as follows:

- Project Data

Project data is required for project participants to understand the background information of the project, such as the project name, address, owner and the construction company.

- 3D Model

BIM technology currently focuses on the visualization of the changing status of the $3 \mathrm{D}$ shapes during the construction process. Therefore, this research integrates the different types of $3 D$ models into the BIM system which includes the building model, excavation model, retaining wall model and supporting elements for visualization.

- Stratum Data

The excavation performance differs according to different ground conditions. This system integrates soil properties and groundwater statuses for environmental impact assessment.

- Analysis Data

Generally, construction project teams will analyze and predict ground settlement using the empirical methods and finite element method before deep excavation. In this research, these results were integrated and visualized in the BIM system to help construction project teams assess environmental impact in a synthesized manner.

- Monitoring Data

Construction project teams normally set up various types of monitoring instruments to collect the necessary data to monitor the status of different environmental variables. The related data integrated into the BIM system includes type, standard value and units recorded by the field monitoring instruments.

In this research, three easy-to-use modules are developed to provide the core services of environmental impact assessment.

\section{Safety / Risk Management}

Adequate risk management during construction is dependent on accurate and on-time reporting of the key measures from the intensive monitoring system. The system can evaluate the probable environmental impacts from the critical monitoring data and BIM, and enable construction project teams to identify and manage risk. Furthermore, the 3D objects (building, excavation and monitoring instruments) are highlighted in different colors according to their risk statuses.

\section{Information Distribution}

Effective visualization assists people in obtaining the required information effectively and efficiently. This system was designed to not only provide sufficient information to facilitate project management, but also provide the various visualization tools to assist with impact assessment and communication. 


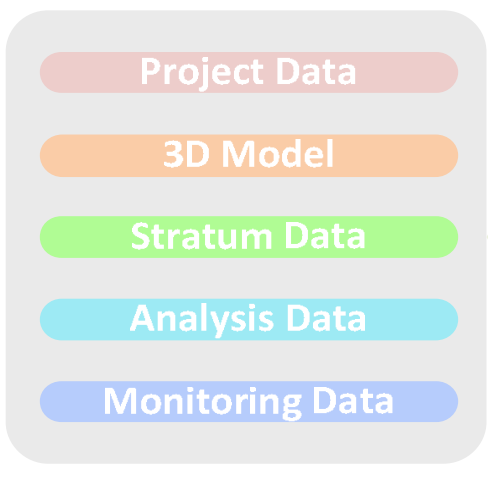

\section{Monitoring Data Management}

The goal of monitoring is to provide useful scientific information about the status and trends of various factors affecting the project's environmental impact. Comprehensive data management functionality is thus essential for achieving this goal, particularly for urban deep excavation.

\section{ENVIRONMENTAL IMPACt ASSESSMENT}

Ground surface settlement can occur during three construction stages: (1) retaining wall construction; (2) groundwater pumping and (3) main excavation. Therefore, project teams need to detect or predict the environmental impacts of these stages to prevent accidents from occurring. This section discusses the environmental impacts and zones of influence associated with the three stages mentioned above, as shown in Table 1. Subsequently, it is shown that how this research integrated these empirical formulas into our BIM system to assist construction project teams in evaluating construction statuses through various visualization tools.

\section{Retaining Wall Construction}

According to the monitoring results of the rapid transit system in Hong Kong, after the completion of the diaphragm walls and before the main excavation, the accumulated deformation was found to be $40-50 \%$ of the total deformation after the completion of the main excavation ${ }^{7}$. Clough and O'Rourke found that the ratio of the maximum settlement induced by the construction of diaphragm walls to the depth of the trench was $0.15 \%$, according to in-situ monitoring results.

\section{Groundwater Pumping}

According to investigations, most problems encountered in deep excavation have direct or indirect relations with groundwater. Groundwater-induced problems in an excavation may arise from insufficient investigation of groundwater or geological conditions. Thus, it is necessary to perform detailed investigations of groundwater and its influences on soils or structures during excavation ${ }^{8}$.
Integration

Safety / Risk

Management

Information

Distribution

Monitoring Data

Management
Visualization
(BIM)

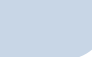

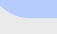

Fig. 1. Research framework

\begin{abstract}
Excavation
Observing the shapes or types of ground surface settlement, we can see that soil at the back of the retaining wall moves forward and down with the retaining wall deforming under normal conditions. Ground settlement will thus be produced ${ }^{8}$. Peck ${ }^{9}$ proposed that the influence zone of settlement should be two or three times that of the excavation depth. Clough and O'Rourke ${ }^{7}$ proposed that excavation in sandy soils may induce a zone of influence of settlement about twice that of the excavation depth ${ }^{8}$.
\end{abstract}

\section{SyStem DESIGn AND IMPLEMENTATION}

The system is implemented based on commercial hardware and software comprising the Bentley MicroStation and InRoads, which supports visualization of the 3D model with some capabilities for 3D object manipulation and information query, with Application Programming Interfaces (APIs) for functionality extensions.

\section{Data Integration and Processing}

As shown in Figure 2, this research designed and developed an integrated BIM model to describe and store information for the entire project, including 3D models, stratum data, analysis data, project data and monitoring data. All of them can be divided into two types, non-graphic data which is stored into a database and $3 \mathrm{D}$ geometry which is stored in the MicroStation object model (.dgn file). Each object (graphic element) that is linked to a database has a database linkage attached to the element. Sometimes, this is called the MSLINK in Bentley System. Therefore, users can double-click the 3D object in MicroStation and summon detailed information on the 3D object that was extracted from the database and vice versa. Besides, monitoring instruments update frequently, so the system needs to provide a batch input function to effectively deal with a large number of monitoring data at any one time.

\section{Visualization}

This system provides three styles of visualization for communication among the project participants as follows: (a) 1D Visualization: attributes of objects and 
general project information; (b) 2D Visualization: graphs and charts of different variables and objects; (c) 3D Visualization: 3D models of building. The visualization examples are shown in Figure 3. We also defined three colours to visualize the different risk statuses in the 3D environment. The different kinds of monitoring instruments are represented by the different 3D primitive solids shown in Table 2 . Table 3 shows the color scheme implemented for displaying risk status.

Table 1. Construction Stages v.s. Environmental impacts

\begin{tabular}{|c|c|c|c|c|}
\hline $\begin{array}{l}\text { Construction } \\
\text { Stage }\end{array}$ & Diagram & $\begin{array}{l}\text { Environmental } \\
\text { Impacts }\end{array}$ & $\begin{array}{l}\text { Monitoring } \\
\text { Data }\end{array}$ & Influence Zone \\
\hline $\begin{array}{l}\text { Retaining Wall } \\
\text { Construction }\end{array}$ & man & $\begin{array}{l}\text { Pile-driving induced } \\
\text { ground shock leads } \\
\text { to cracking in adja- } \\
\text { cent structures and } \\
\text { settlement. }\end{array}$ & $\begin{array}{ll}\text { 1. } & \text { Building } \\
& \text { Settlement } \\
& \text { Point (SB) } \\
\text { 2. } & \text { Settlement } \\
& \text { Point (SM) } \\
\text { 3. } & \text { Tiltmeter } \\
& \text { Point (TI) }\end{array}$ & $\begin{array}{l}\mathrm{d}=0.5 \mathrm{H}_{\mathrm{t}} \\
\text { Where } \mathrm{H}_{\mathrm{t}} \text { is the } \\
\text { depth of a } \\
\text { trench })^{10}\end{array}$ \\
\hline $\begin{array}{l}\text { Groundwater } \\
\text { Pumping }\end{array}$ & $\overbrace{\substack{\text { she } \\
\text { sand }}}^{\uparrow}$ & $\begin{array}{l}\text { Pumping causes } \\
\text { lowering of ground } \\
\text { water table which } \\
\text { increases the effec- } \\
\text { tive stress on soft } \\
\text { clay and results in } \\
\text { consolidation settle- } \\
\text { ment. }\end{array}$ & $\begin{array}{l}\text { 1. Settlement } \\
\text { Point (SM) } \\
\text { 2. Standpipe } \\
\text { Piezome- } \\
\text { ter (PS) }\end{array}$ & $\begin{array}{l}\mathrm{Q}=\frac{2 \pi \mathrm{kD}\left(\mathrm{s}_{1}-\mathrm{s}_{2}\right)}{\ln \left(\mathrm{r}_{2-\mathrm{r}_{1}}\right)} \\
\mathrm{Q}=\text { Discharge } \\
\text { Quantity } \\
\text { by Theis }(1935)^{11}\end{array}$ \\
\hline Excavation & $\begin{array}{l}\text { Spandrel type of } \\
\text { settlement } \\
\text { Retaining } \\
\text { Wall } \\
P I Z=\text { potential failure zone. }\end{array}$ & $\begin{array}{l}\text { Excavation causes } \\
\text { excessive wall deflec- } \\
\text { tions which may then } \\
\text { induce adverse } \\
\text { movements to adja- } \\
\text { cent foundations, } \\
\text { leading to large sur- } \\
\text { face settlement, and } \\
\text { cracking of pave- } \\
\text { ments. }\end{array}$ & $\begin{array}{ll}\text { 1. } & \text { Building } \\
& \text { Settlement } \\
& \text { Point }(\mathrm{SB}) \\
\text { 2. } & \text { Settlement } \\
& \text { Point (SM) } \\
\text { 3. } & \text { Tiltmeter } \\
\text { Point (TI) }\end{array}$ & $\begin{array}{l}P I Z_{1}=\min \left(2 H_{\mathrm{e}}, H_{\mathrm{g}}\right) \\
H_{\mathrm{e}}=\text { The excava- } \\
\text { tion depth and } \\
H_{\mathrm{g}}=\text { The depth of } \\
\text { the hard soil. } \\
P I Z_{2}=\min \left(2 H_{\mathrm{f}}, \mathrm{B}\right) \\
H_{\mathrm{f}}=\text { the depth of } \\
\text { the soft clay bot- } \\
\text { tom and } B=\text { The } \\
\text { excavation width. } \\
P I Z=\max \left(P I Z_{1}, P I Z\right. \\
\text { 2) }\end{array}$ \\
\hline
\end{tabular}

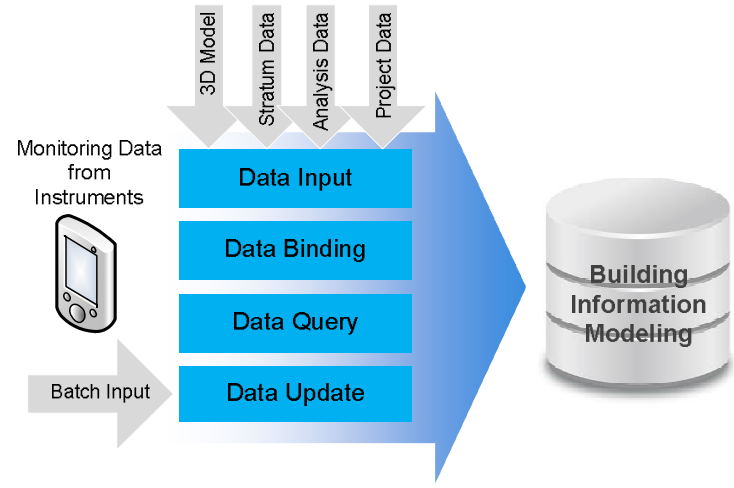

Table 3. Color schema for risk management

\begin{tabular}{|c|c|}
\hline Color & Status \\
\hline Green & Safe. \\
\hline Yellow & $\begin{array}{l}\text { Warning. Please adopt mitigation } \\
\text { measures to reduce the risk level. }\end{array}$ \\
\hline Red & $\begin{array}{l}\text { Dangerous. Please take adopt mitiga- } \\
\text { tion measures urgently to reduce the } \\
\text { risk level. }\end{array}$ \\
\hline
\end{tabular}

Fig. 2. The data processing workflow

Table 2. The 3D representation of monitoring instruments

\begin{tabular}{|c|l|c|l|}
\hline 3D Solid & \multicolumn{1}{|c|}{ Description } & 3D Solid & \multicolumn{1}{c|}{ Description } \\
\hline & Building Settlement Point (SB) & & Standpipe Piezometer (PS) \\
\hline & Settlement Point (SM) & & Tiltmeter Point (TI) \\
\hline
\end{tabular}




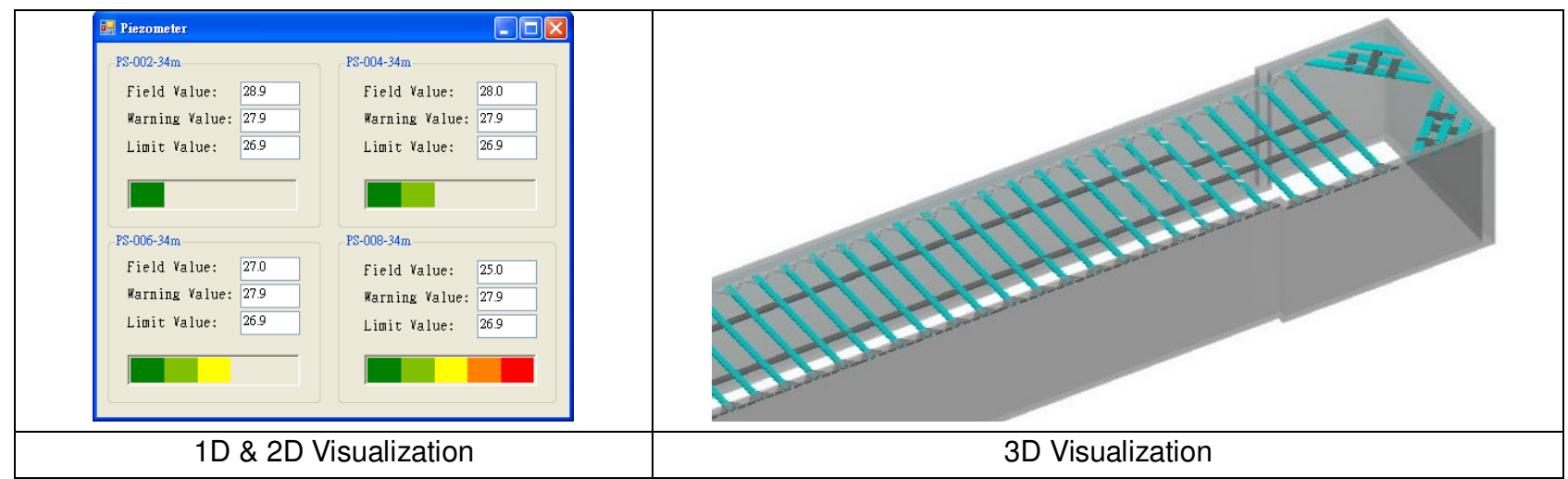

Fig.3. The various visualization types provided in the BIM system

\section{DEMONSTRATION}

\section{Engineering Example}

Excavation of $\mathrm{O} 6$ station in Kaohsiung metro system was selected as the project background. Kaohsiung is the economic and political centre of southern Taiwan, its metro project of the city was commenced since 2001. The O6 Station is located in the junction of Chung-Cheng Road and Ming-Chu Road and the surrounding of $\mathrm{O} 6$ Station is populous as shown in Figure 4. It was constructed by cut-\&-cover method and the maximum excavation depth is $19.6 \mathrm{~m}$. The pit was retained by a $1 \mathrm{~m}$ thick, $36 \mathrm{~m}$ deep reinforcement concrete diaphragm wall. The major structure of $\mathrm{O} 6$ Station is a 2-level basement. The main soil strata of the site consist of the groundwater level was observed at $3.5 \mathrm{~m}$ below surface level. Details of the project are stated by Hsiung ${ }^{13}$. In such a complex environment, construction project team must pay more attention on environmental impacts during deep excavation. Instruments installed on site include inclinometers in soils and diaphragm walls, settlement points, tiltmeters, piezometers etc.

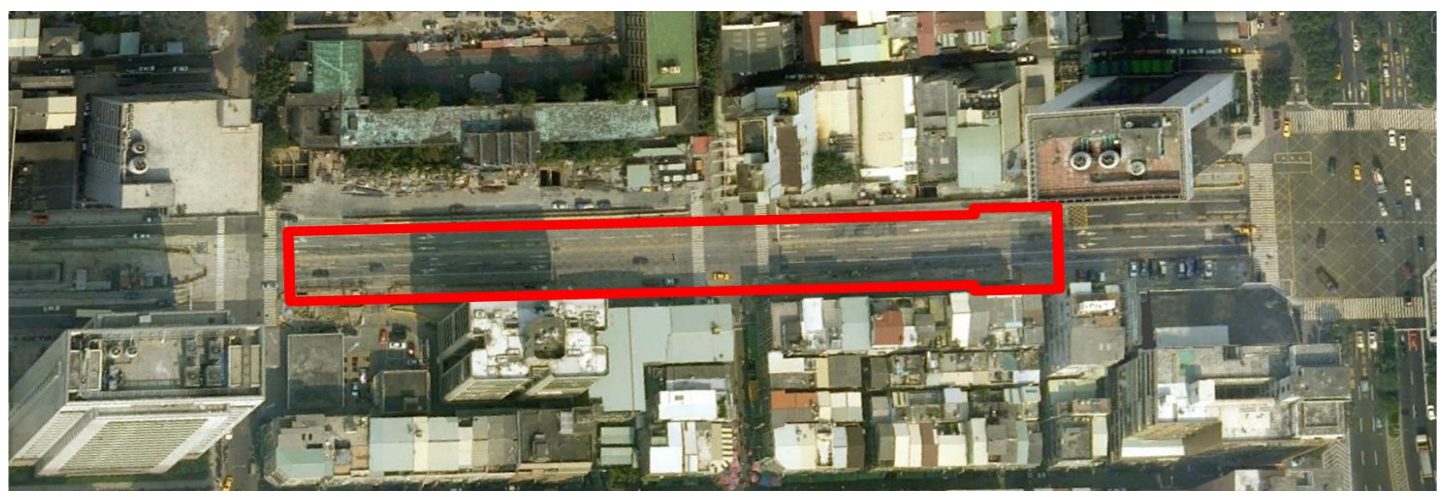

Fig.4. The main excavation zone of 06 station in Kaohsiung

\section{Safety / Risk Management}

Stratum data is integrated and visualized in the BIM system, as shown in Figure 5(a). These ground conditions are important references for selecting the appropriate excavation method. Adopting suitable excavation methods can reduce risks. Moreover, the BIM system can visualize the zone of influence of deep excavation (developed by the previous researcher), as shown in Figure 5(b). It can provide essential information for assisting planners in assessing environmental impacts comprehensively for safety and risk management.

\section{Monitoring Data Management}

The construction project team can input monitoring data from the graphical user interface or database, as shown in Figure 6(a). The system will subsequently update the status representation of environmental impacts by comparing field values and standard values, as shown in Figure 6(b). The construc- tion project team can also view the overall status of the excavation project, as shown in Figure 6(c).

\section{Conclusions}

Risk assessment is an important task for urban deep excavation projects. This research took advantage of information integration and visualization capabilities of BIM to assist planners with assessing possible environmental impacts. This study demonstrated the use of the BIM model of a deep excavation project to integrate the 3D model and the relevant information about retaining walls, excavation and adjacent buildings, and then visualized all of the results of analysis and assessment to show the likely locations and degrees of risk and safety, under different situations, so that users can quickly obtain the necessary information to make the necessary decisions and evaluations to solve problems and plan appropriate emergency measures. 


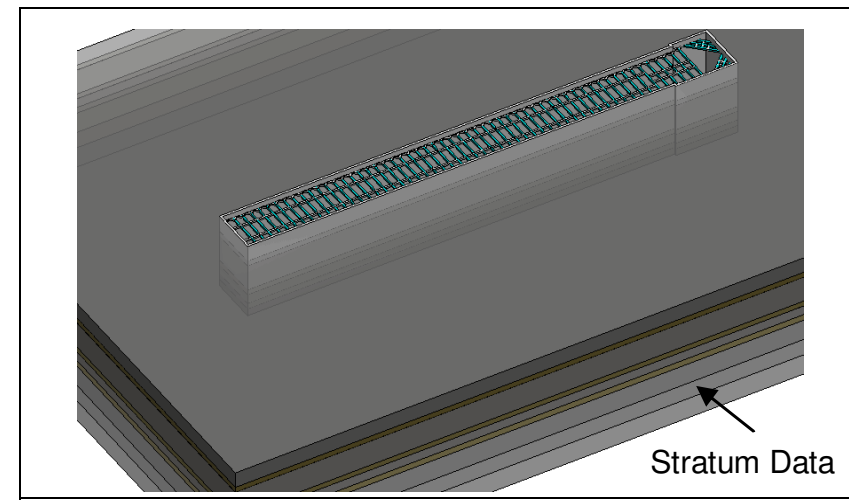

(a) Stratum data for environmental impact assessment

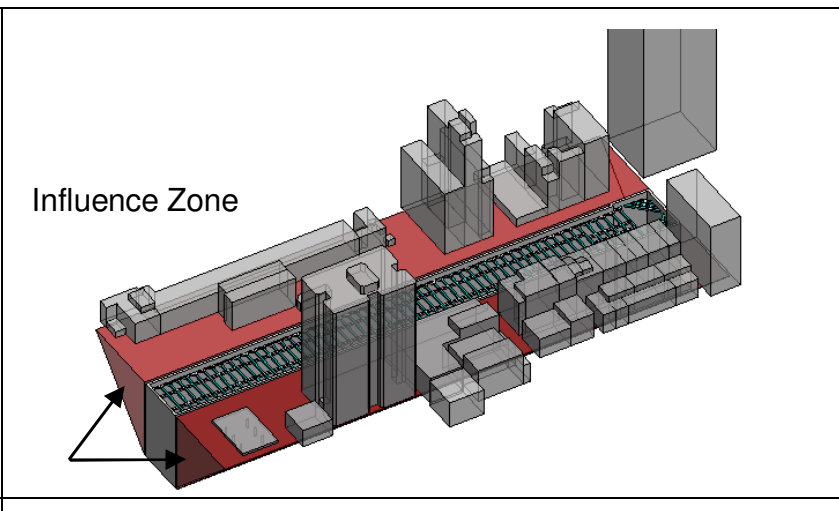

(b) Zone of influence of ground surface settlement

Fig.5. Safety / Risk Management

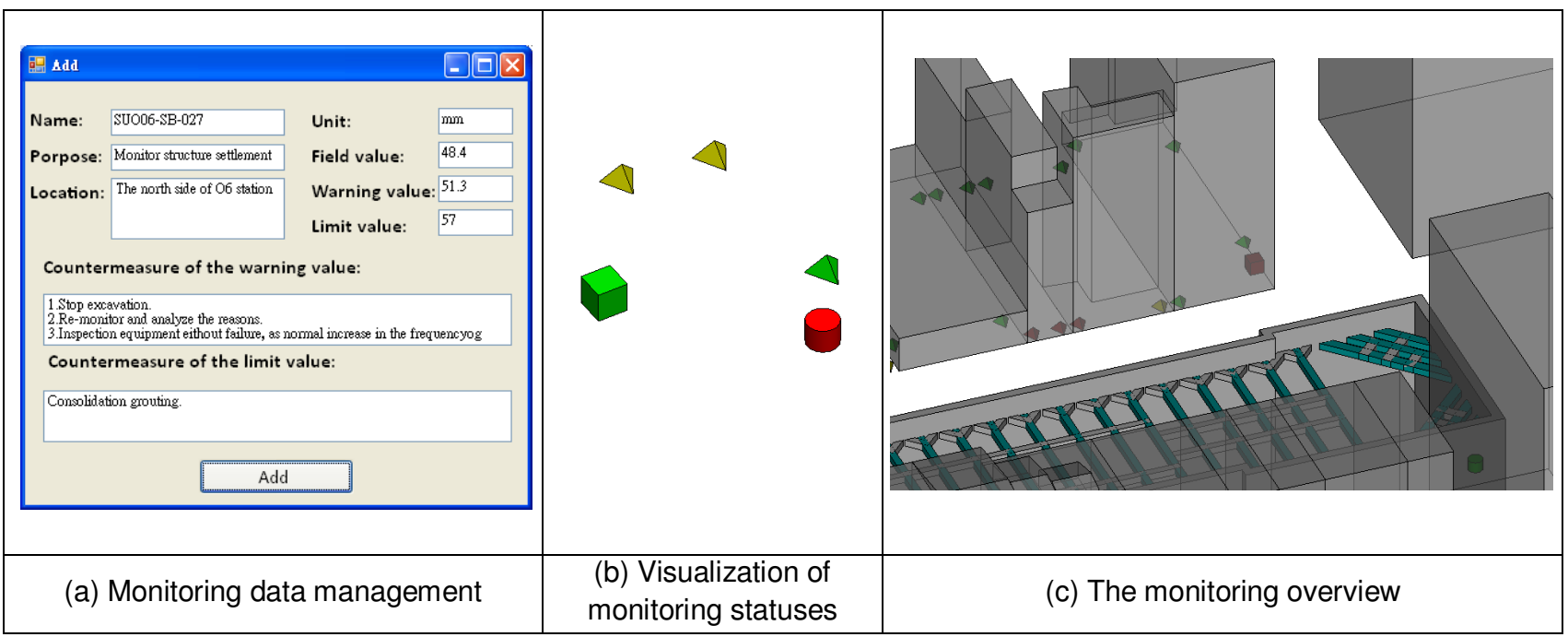

Fig.6. Monitoring data management

\section{References}

1. Peck, R.B., "Deep excavations and tunneling in soft ground", Proceedings of the $7^{\text {th }}$ International Conference on soil mechanics and foundation engineering, Mexico City, State-of-the-Art, 1976.

2. Bowles, J.E., "Foundation analysis and design", $4^{\text {th }}$ edition, McGraw- Hill, New York, USA, 1988.

3. Clough, G.W. and O'Rourke, T.D., "Constructioninduced movements of in situ walls", Design and Performance of Earth Retaining Structure, ASCE Special Publications, No. 25, pp. 439- 470, 1990.

4. Ou, C.Y., Hsieh, P.G. and Duan, S.M. "A simplified method to estimate the ground surface settlement induced by deep excavation", Geotechnical Research Report, No.GT200502, Department of Construction Engineering, National Taiwan University of Science and Technology, 2005.

5. Eastman, C., Teicholz, P., Sacks, R., and Liston, K., BIM Handbook: A Guide to Building Information Modeling for Owners, Managers, Designers, Engineers and Contractors, Wiley, pp. 504, 2008.

6. Elbeltagi, E., and Dawood, M., "Integrated visualized time control system for repetitive construction projects", Automation in Construction, Vol. 20(7), pp. 940-953, 2011.
7. Clough, G.W. and O'Rourke, T.D., "Constructioninduced movements of in situ walls", Design and Performance of Earth Retaining Structures, ASCE Special Publication, No.25, pp.439-470, 1990.

8. Ou, C.Y., Deep Excavation: Theory and Practice. Taylor \& Francis, Netherlands, 2006.

9. Peck, R.B., "Deep excavation and tunneling in soft ground", Proceedings of the 7th International Conference on soil Mechanics and Foundation Engineering, Mexico City, State-of-the-Art Volume, pp. 225-290,1969.

10. Ou, C.Y. and Yang, L.L., "Ground movement Induced by the construction of diaphragm wall", Geotechnical Research Report, No. GT200005, Department of Construction Engineering, National Taiwan University of Science and Technology, Taipei, Taiwan, R.O.C, 2000.

11. Theis, C.V., "The relation between the lowering of the piezometric surface and the rate and discharge of a well using ground water storage", Transactions of the American Geophysical Union16th Annual Meeting.

12. Hsieh, P.G. and Ou, C.Y., "Shape of Ground Settlement Profiles Caused by Excavation" Canadian Geotechnical Journal, Vol. 35(6), pp. 1004-1017, 1998. 
13. Hsiung, B.C., "A case study on the behaviour of a deep excavation in sand", Computer and Geotechnics, Vol. 36(4), pp. 665-675, 2009. 